\title{
Mini-Review: The Influence of User Behavior on the Success of Information System Implementation: Towards the Development of Behavior-Based Information System Requirements
}

\author{
Sali Alas $M^{1,4^{*}}$, Purwanto ${ }^{1,2}$, and Farikhin ${ }^{1,3}$ \\ ${ }^{1}$ Doctoral Program of Information System, School of Postgraduate Studies, Diponegoro University, \\ 50241 Semarang Indonesia \\ ${ }^{2}$ Department of Chemical Engineering, Faculty of Engineering, Diponegoro University, 50275 \\ Semarang Indonesia \\ ${ }^{3}$ Department of Mathematics, Faculty of Science and Mathematics, Diponegoro University, 50275 \\ Semarang Indonesia \\ ${ }^{4}$ Department of Informatics Engineering, Faculty of Engineering, Pasundan University, 40153 \\ Bandung Indonesia
}

\begin{abstract}
The characteristics and behaviour of information system users have a big influence on the successful implementation of information systems. There have been many studies that reveal the effects of user behaviour related to technology and information systems. The majority of research conducted deals with the impact of culture on user behaviour after the implementation of information systems. Very few journals discuss how the characteristics and factors of user behaviour are used as inputs that affect the information system development process. This research was conducted to conduct a literature review regarding the dominant factors in user behaviour and to see their impact on the development of information systems. The results of the study are in the form of synthesis to see the opportunity to include these user behaviour factors into components of the information system requirements.
\end{abstract}

\section{Introduction}

Failures in the application of information systems (S.I.) are still often heard. This refers to a study a few years ago which mentioned about $80 \%-90 \%$ of S projects. I failed to fulfil the wishes of its users [1]. Likewise, the statement that the development of I.S. projects, failures are still common, about $18 \%$ of S.I. projects in 2012 have failed [2].

One of the causes of failures encountered was that the implementation of information systems clashed with the organizational culture [3].

\footnotetext{
* Corresponding author: salialasm@students.undip.ac.id
} 
In another study, it was stated that the "changing mindsets and attitudes" category was ranked first with a total of $58 \%$, while the second rank was "corporate culture" with a total of $49 \%$ [4].

Lamb and Kling's research [5] states that one of the most important factors in an information system is the user. Research on users is considered to make a significant contribution in optimizing the benefits of information technology.

Several studies on users are associated with culture and behaviour $[6,7,8,9,10]$, it is stated that user behaviour is influenced by environment and culture. Many studies on behavior relate it to cultural factors $[11,12,13,14,15]$.

This study shows many user factors that are considered to affect the success of the implementation of information systems. The user factors presented are the result of a review of some journals, which are compiled in such a way into discussion groups according to previously existing behavioural theories. The research also conveys some opinions that are considered relevant that can show how the factors of user behaviour can affect the implementation of information systems.

\section{Review Methodology}

The review is focused on a wide variety of user behaviour information technology, which is obtained from surveys in several information system journals. The journal was obtained using several source databases.

There are approximately 1078 papers published in these journals from January 2005 to December 2020. Then the selection and grouping are carried out, and the similarity analysis is carried out.

The steps taken are as follows:

a. Searching Methodology

Establish research objectives with a focus on the following questions:

- RQ1: How is the user relationship with the successful implementation of information systems?

- RQ2: What are the theories related to user behaviour?

- RQ3: What are the dimensions and dominant factors of user behaviour?

Based on the questions above, an Initial Query-Based search was conducted to obtain as much literature as possible in scientific databases, namely, MIS Quarterly, Science Direct, Google Scholar, and Scopus. From the search results, the result of Query-Based Search is obtained as shown in Table 1.

Table 1. Query-Based Search.

\begin{tabular}{|l|c|c|c|c|}
\hline Source Database & $\begin{array}{c}\text { Total } \\
\text { Result }\end{array}$ & $\begin{array}{c}\text { Removal of Duplicates } \\
\text { AND Language }\end{array}$ & $\begin{array}{c}\text { Elimination } \\
\text { Irrelevant }\end{array}$ & $\begin{array}{c}\text { Relevant } \\
\text { Sample }\end{array}$ \\
\hline Scopus & 200 & 8 & 152 & 40 \\
\hline Science Direct & 54 & - & 38 & 16 \\
\hline Google Scholar & 748 & 78 & 602 & 68 \\
\hline MIS Quarterly & 76 & - & 15 & 61 \\
\hline Total & 1078 & 86 & 807 & 185 \\
\hline
\end{tabular}

b. Literature Selection

To ensure consistency, a selection and comparison process was carried out between articles and recorded similarities and statements for each behavioural factor. Following the guidelines made by Larsson [16], all discrepancies were re-analyzed by looking at the suitability of the case in the study. This process helps refine some inclusion and 
exclusion criteria and increases the validity of the review process. In the next step, according to the principle of Petticrew \& Roberts systematic review [17], the decision to include/not include papers in the study was made based on the assessment of the title and abstract. The final results obtained 112 articles/papers.

c. Synthesis

Furthermore, grouping is carried out based on understanding from the literature, namely: grouping based on antecedents and the impact of user behaviour [18], and grouping based on the acceptance/rejection relationship to user requirements and resistance [19].

\section{Result and Discussion}

\subsection{Dimensions of Information Technology User Behaviour}

Several factors refer to the theory of technology acceptance and the impact of individual behaviour. Table 2 shows the theory and model of the behavioural system and its behaviour variables.

Table 2. Theories and models of behavioral antecedents [18].

\begin{tabular}{|l|l|l|}
\hline \multicolumn{2}{|c|}{ Theory } & \multicolumn{1}{|c|}{ Behavioural Determinants } \\
\hline a. & $\begin{array}{l}\text { Theory of Reasoned Action (TRA) } \\
\text { by Fishbein and Ajzen [20]. }\end{array}$ & Attitude toward behaviour, Subjective norm \\
\hline b. & $\begin{array}{l}\text { Technology Acceptance Model } \\
\text { (TAM) by Davis et al. [21]. }\end{array}$ & $\begin{array}{l}\text { Perceived usefulness, Perceived ease of use, } \\
\text { Subjective norm }\end{array}$ \\
\hline c. & $\begin{array}{l}\text { Theory of Planned Behaviour } \\
\text { (TPB) by Ajzen [22]. }\end{array}$ & $\begin{array}{l}\text { Attitude toward behaviour, Subjective norm, } \\
\text { Perceived behaviour control }\end{array}$ \\
\hline d. & $\begin{array}{l}\text { Decomposed Theory of Planned } \\
\text { Behaviour (DTPB) by Taylor and } \\
\text { Tood [23] }\end{array}$ & $\begin{array}{l}\text { Interpersonal influence, External influence, Perceived } \\
\text { usefulness, Perceived risk, Perceived playfulness or } \\
\text { Perceived Enjoyment, Self-Efficacy, Perceived } \\
\text { controllability }\end{array}$ \\
\hline e. & $\begin{array}{l}\text { Innovation Diffusion Theory (IDT) } \\
\text { by Taylor \& Todd [24]. }\end{array}$ & $\begin{array}{l}\text { Attitude toward behaviour, Subjective norm, } \\
\text { Perceived behaviour control, Perceived usefulness }\end{array}$ \\
\hline f. & $\begin{array}{l}\text { Model of PC Utilization (MPCU) } \\
\text { by Thompson et al [25]. }\end{array}$ & $\begin{array}{l}\text { Job-Fit, Complexity, Long-term consequences, } \\
\text { Affect towards use, Social factors, Facilitating } \\
\text { conditions }\end{array}$ \\
\hline g. & $\begin{array}{l}\text { Social cognitive theory (SCT) by } \\
\text { Compeau dan Higgins [26]. }\end{array}$ & $\begin{array}{l}\text { Outcome expectations- performance, Outcome } \\
\text { expectations-personal, Self-efficacy, Affect, Anxiety }\end{array}$ \\
\hline h. & $\begin{array}{l}\text { Unified Theory of Acceptance and } \\
\text { Use of Technology (UTAUT) by } \\
\text { Venkatesh et al. [27] }\end{array}$ & $\begin{array}{l}\text { Performance expectancy, Effort Expectancy, Social } \\
\text { influence, Facilitating conditions, four variable } \\
\text { moderation (Gender, Age, Experience, Voluntariness } \\
\text { of use) }\end{array}$ \\
\hline
\end{tabular}

Other theories and models are behavioural theories with an antecedent in the form of a process. Variables related to antecedents in the form of processes are shown in table 3.

Table 3. Theory and Model Antecedents in the form of processes [18].

\begin{tabular}{|l|l|l|}
\hline \multicolumn{2}{|c|}{ Theory } & \multicolumn{1}{c|}{ Behavioural Determinants } \\
\hline a. & $\begin{array}{l}\text { Coping Model of User Adoptation } \\
\text { (CMUA) by Beaudry \& Pinsonneault } \\
{[28] .}\end{array}$ & $\begin{array}{l}\text { Primary Appraisal, Secondary Appraisal, } \\
\text { Adaptation strategies, Individual efficiency, and } \\
\text { effectiveness, Minimiz negative, consequences, } \\
\text { Restoring personal emotional stability }\end{array}$ \\
\hline
\end{tabular}




\begin{tabular}{|l|l|l|}
\hline \multicolumn{1}{|c|}{ Theory } & \multicolumn{1}{|c|}{ Behavioural Determinants } \\
\hline b. & $\begin{array}{l}\text { User Participation and User } \\
\text { Involvement (UPUI) by Barki et. al. } \\
\text { [29] and Jarvenpaa \& Ives [30]. }\end{array}$ & $\begin{array}{l}\text { User Participating, User Involvement, } \\
\text { Organizational conditions, User Background, } \\
\text { Progressive use }\end{array}$ \\
\hline c. & $\begin{array}{l}\text { Task Technology Fit by Goodhue dan } \\
\text { Thompson [31], Dishaw dan Strong }\end{array}$ & $\begin{array}{l}\text { Task characteristics, Technology characteristics, } \\
\text { Task technology fit, Utilization, Performance } \\
\text { impacts }\end{array}$ \\
& $\begin{array}{l}\text { [32], Dishaw et al [33], Goodhue [34], } \\
\text { Zigur dan Buckland [35], Zigur et al } \\
\text { [36] }\end{array}$ & \\
\hline
\end{tabular}

Another model is a model that looks at and focuses on the successful implementation of information systems at the organizational level. The variables of the success model are shown in table 4.

Table 4. Theory and Models of Influence of Behaviour on Organizations [18].

\begin{tabular}{|l|l|l|}
\hline \multicolumn{2}{|c|}{ Theory } & \multicolumn{1}{c|}{ Behavioural Determinants } \\
\hline a. & $\begin{array}{l}\text { Information System Success } \\
\text { Model by DeLone \& } \\
\text { McLean [37] }\end{array}$ & $\begin{array}{l}\text { Primary Appraisal, Secondary Appraisal, Adaptation } \\
\text { strategies, } \\
\text { Individual efficiency and effectiveness, Minimiz negative, } \\
\text { consequences, Restoring personal emotional stability }\end{array}$ \\
\hline b. & $\begin{array}{l}\text { Updated Information } \\
\text { System Success Model by } \\
\text { DeLone \& McLean [38] }\end{array}$ & $\begin{array}{l}\text { User Participating, User Involvement, Organizational } \\
\text { conditions, User Background, Progressive use }\end{array}$ \\
\hline
\end{tabular}

\subsection{Categories of User Behaviour Influence on Information System Development}

Leidner and Keyworth [39,40] have identified a total of 85 research projects dealing with the influence of both national and organizational behaviour and culture on information systems. The research is divided into six topic areas (IS Culture and Development, Culture, IT adoption and diffusion, Culture, IT Usage and Outcomes, Culture, IT Management, and Strategy, Influence of IT on Culture, IT Culture). Adherence to cultural requirements for systems and products can significantly influence success, and therefore has special relevance [41].

Another approach is taken by adopting the opinion of Riri Astria [42] which categorizes influence into 4 categories:

a. User Behavior as a process

Several studies in this category were carried out by Brown, S. A., V. Venkatesh [43], who stated that the benefits of IT, normative values adopted, self-perceptions to master the technical use of IT affect a person's decision to adopt IT to the organization. Likewise with research Feng [44] and research conducted by Avgerou and McGrath $[42,45]$.

In the research on user behaviour, the appropriate groups associated with this category are theories and models with antecedents in the form of processes. Behavioural research variables with antecedents in the form of processes can be seen in Table 2.

b. User Behavior as an accelerator

Research related to accelerators, for example, is found in the research of Ahuja, M. K., J. B. Thatcher [46]. Other research is by Karahanna, E. and R. Agarwal, and C. M. Angst [47], with a focus on the components of perception of benefits and perceptions of ease of use. While the research of Paul, D. L. and R. R. McDaniel Jr [48] looks at the factors that will make users optimize IT as a medium for virtual collaboration in their work. The influencing component is interpersonal trust which consists of personal 
Interest, ability, empathy, and trust in the system. User behaviour research that can fit into this category is mainly the theories about participation by Barki et al. [29], Jarvenpaa \& Ives [30] and task-technology fit theory by Dishaw et al. [33] and Goodhue [34]. Several related variables can be seen in Table 2.

c. User Behavior as an accelerator (Post - Implementation)

The studies that fall into this category are those of Beaudry A and Pinsonneault A $[28,42]$. IT users make adjustments to existing IT after implementation. The components that are the focus of the research are the emotional stability of users after going through a phase of change due to IT implementation (restoring personal emotional stability), then effective and efficient behaviour at work, as well as initiatives to participate in minimizing negative impacts after IT implementation.

The research of Jasperson, J., P. E. Carter, R. W. Zmud [49] was conducted with more focus on the cognitive aspects of IT users. Other studies, for example, by Gattiker, T. F., and D. L. Goodhue [50], highlight the post-implementation results of ERP that are not always able to form a coordinating culture between various parties within the organization, even though ERP itself aims to improve integration and coordination.

In this category, user behaviour studies with a behavioural influence model on organizations are acceptable. Several studies such as that were conducted by Delon McLean [37,38]. The variables related to behaviour for behavioural antecedents and user acceptance can be seen in Table 3.

d. User Behavior as input for the design and implementation plan

Research related to culture as input for design shows more user involvement in development projects [6]. Several studies related to inputs for design include Feng [44], Avgerou, C., and McGarth [45].

User behaviour research that can fit into this category is primarily researching behavioural antecedents in the context of user acceptance. The variables related to behaviour for behavioural antecedents and user acceptance can be seen in Table 1, which consists of approximately 35 variables about the behaviour.

\section{Conclusions}

The results of the review obtained behavioural factors taken from several articles. Factors are grouped into two approaches, namely, based on behavioural antecedents and their impact [18].

Based on the first approach, 13 theories and models were identified with 64 variables. Meanwhile, based on the second approach, there are 18 factors with 34 resistance impacts.

This study did not do a synthesis to look for similarities in factors or variables, so it is suspected that there is duplication of several factors and variables in either the same approach or in the two approaches taken. To obtain variable unification, it is necessary to carry out additional activities in the form of synthesis of the factors and variables obtained.

To see the effect of user behaviour, this study adopts the opinion of Leidner and Keyworth [40] taken in the Kummer article [51] and Riri Austria's article [42]. The effects are grouped into four categories [42], namely (1) input for design, (2) process for design, (3) implementation outcomes, (4) accelerator.

As a prospect, the research can be continued by comparing the effect of user behaviour obtained from this study with other models, such as Anne Beaudry's model [19], which divides the effect based on user retention on information technology which shows the manifestation of the relationship between user behaviour conformity/incompatibility with technology usage requirements. This model has four quadrants, namely Acceptance, Resistance, Conformity, and Non-Conformity. 
This article is preliminary research that needs to be continued and linked with other research sub-studies to achieve the main objectives of the real research. Given the high heterogeneity of research in this area, the authors find it necessary to undertake quality and systematic analysis of the literature to determine which results to use and determine which research questions remain unanswered.

\section{References}

1. Cabrera, A., Cabrera, et al., The Key Role of Organizational Culture in a Multi-System View of Technology-Driven Change, International Journal of Information.Vol.21, num.3, p.245- 261.Elsevier.ISSN 0268-4012 (2001)

2. Standish Report, Chaos Manifesto 2013, (2013)

3. Claver, E, Llopis, J, Gonzalez, The performance of Information Systems Through Organizational Culture, Information Technology \& People, vol. 14,-260.no 3, pp.247 (2001)

4. IBM Institute for Business Value, Global Change Management Study, Making Change Work, IBM-USA (2008)

5. Lamb, Roberta; Kling, R., Reconceptualizing Users as Social Actors in Information Systems Research, MIS Quarterly; 27(2) (2003)

6. Dorothy E. Leidner and Timothy Kayworth, Review: A Review of Culture in Information Systems Research: Toward a Theory of Information Technology Culture Conflict, MIS Quarterly 30(2):357-399 (2006)

7. Yi Zhou, Jianliang Wei, Fei Meng, and Fen Jiang, Influential Factors and User Behavior of Mobile Reading, Journal of Intelligent Systems, 24(2): 223-234 (2015)

8. Lisa Rosiana, Musa Hubeis, Eko Ruddy Cahyadi, Factors Affecting User Behavior of Technology Application of Management Information System, Indonesian Journal of Business and Entrepreneurship, Vol. 6 No. 3, September (2020)

9. Wanyama G. Indeje, Qin Zheng, Organizational Culture and Information Systems Implementation: A Structuration Theory Perspective, AIS eLibrary (2010)

10. Siti Mardiana, Jann Hidajat Tjakraatmadja, Atik Aprianingsih, How Organizational Culture Affects Information System Success: The Case of an Indonesia IT-Based Company, Journal of Information Systems Engineering, and Business Intelligence, Vol.4, No.2, October (2018)

11. Danar Retno Sari, Teduh Dirgahayu, Pengaruh Dimensi Budaya Terhadap Perilaku Penggunaan E-commerce: Daerah Istimewa Yogyakarta, INTENSIF, UNP Jogjakarta (2018)

12. Vajehe Rahmati, Soheila Darouian, Hamed Ahmadinia A, Review on Effect of Culture, Structure, Technology, and Behavior on Organizations, Australian Journal of Basic and Applied Sciences (2012)

13. Lee Cronk, Culture's Influence on Behavior: Steps Toward a Theory, Evolutionary Behavioral Sciences, Vol. 11, No. 1, 36-52 (2017)

14. Tianya LI, Organizational Culture \& Employee Behavior, Bachelor's Thesis in Business Information Technology, Spring (2015)

15. Joseph Henrich, Culture and Social Behavior, Science Direct, 3:84-89 (2015)

16. Larsson, R., Case survey methodology: quantitative analysis of patterns across case studies, The Academy of Management Journal, Vol. 36 No. 6, pp. 1515-1546 (1993) 
17. Petticrew, M; Roberts, H, Systematic reviews-do they work in informing decisionmaking around health inequalities? Health economics, policy, and law, 3 (Pt 2). pp. 197-211 (2008)

18. HM, Jogiyanto, Sistem Informasi Keperilakuan, Ed. 1, Penerbit Andi, Jogjakarta (2007)

19. Beaudry, A.; Vaghefi, I., Lapointe, L. \& Bagayogo, F., Impacts of IT User Behavior: Observations Through A New Lens, AIS Journal, vol. 46 (2020)

20. Fishbein, M., and Ajzen, I., Belief, Attitude, Intention, and Behavior: An Introduction to Theory and Research, Addison-Wesley, Reading, MA (1975)

21. Davis FD, Perceived Usefulness, Perceived Ease of Use, and User Acceptance of Information Technology, MIS Quarterly 13(3), 319-340 (1989)

22. Ajzen, I., The Theory of Planned Behavior: Organizational Behavior and Human Decision Process, (50:2), pp. 179-211 (1991)

23. Taylor, S., \&Todd, P, Decomposition and crossover effects in the theory of planned behavior: A study of consumer adoption intentions, International Journal of Research in Marketing, 12, 137-155 (1995)

24. Taylor S, and Todd PA, Understanding Information Technology Usage: A Test of Competing Models, Information Systems Research 6(2), 144-176 (1995)

25. Thompson, R. L., Higgins, C.A, and Howell, J. M, PersonalComputing: Toward a Conceptual Model of Utilization, MIS Quarterly (15:1), pp.124-143 (1991)

26. Compeau DR and Higgins CA, Application of the Social Cognitive Theory to Training for Computer (1995)

27. Venkatesh V, Morris MG, Davis GB, and Davis FD, User Acceptance of Information Technology: Toward a Unified View, MIS Quarterly 27(3), 425-478 (2003)

28. Beaudry A and Pinsonneault A, Understanding User Responses to Information Technology: A Coping Model of User Adaptation, MIS Quarterly 29(3), 493-524 (2005)

29. Barki, H., and Hartwick, J. M., User Participation and User Involvement in Information System Development, Proceedings of Hawaiian International Conference on the System Science, pp. 487-492 (1991)

30. Javerpaa, S. L., and Ives, B., Executive Involvement and Participation in The Management of Information Technology, MIS Quarterly, pp.205-226 (1991)

31. Goodhue, D. L, and Thompson, R. L., Task-Technology Fit and Individual Performance, MIS Quarterly (09:2), pp. 213-236 (1995)

32. Dishaw, M. T., Strong, D.M, Extending the Technology Acceptance Model with Task-technology Fit Constructs, Information, and Management (36:1), pp. 9-21 (1999)

33. Dishaw, M. T., Strong, D.M., Brandy D. B, Extending the Task-technology Fit Model with Self-Efficacy Constructs, in Proceedings of the 8th Americas on Information System, R. Ramsower and J. Windsor (Eds), Dallas, TX, pp. 1021-1027 (2002)

34. Goodhue, D.L., Understanding User Evaluations of Information System, Management Science (41:12), pp. 1827-1844 (1995)

35. Zigurs, I, Buckland, B.K, A Theory of Task-Technology Fit and Group Support System Effectiveness, MIS Quarterly, (22:2), pp. 313-334 (1998) 
36. Zigurs, I, Buckland, B.K, Connolly, J.R., Wilson, E.V., A Test of Task-Technology Fit Theory for Group Support Systems, The Database for Advances in Information System (30:3,4), Summer-Fall, pp. 34-50 (1999)

37. DeLone W and McLean E, Information Systems Success: The Quest for the Dependent Variable, Information Systems Research 3(1), 60-95 (1992)

38. Delone W and McLean E, The DeLone and McLean Model of Information Systems Success: A TenYear Update. Journal of Management. Information System 19(4), 9-30 (2003)

39. Gallivan M, Srite M, Information technology and culture: identifying fragmentary and holistic perspectives of culture, Inf Organ 15(4):295-338 (2005)

40. Leidner DE, Kayworth T, A review of culture in information systems research: towards a theory of information technology culture conflict, Manage Inf Syst Q 30(2):357-399 (2006)

41. Marcus A, Gould EW, Crosscurrents: cultural dimensions and global Web userinterface design, Interactions 7(4):32-46 (2000)

42. Riri Satria, Penelitian Aspek Budaya pada Sistem Informasi, Jurnal Sistem Informasi July 2012. Universitas Indonesia (2012)

43. Brown, S. A., V. Venkatesh, Model of Adoption of Technology in Households: A Baseline Model test and Extension Incorporating Household Life Cycle, MIS Quarterly, Vol. 29, No 3, September 2005: pg. 399-426 (2005)

44. Feng, X., Information Systems Management and Culture: Experiences from a Chinese Perspectives, Ph.D. Dissertation, Technische Universiteit Eindhoven (2003)

45. Avgerou, C., McGarth, Power, Rationality, and the Art of Living through SocioTechnical Change, MIS Quarterly, Vol. 31, Issue 2, Juni 2007: pg. 295-315 (2007)

46. Ahuja, M. K., J. B. Thatcher, Moving Beyond Intentions and Toward the Theory of Trying: Effects of Work Environment and Gender on Post-Adoption Information Technology Use, MIS Quarterly, Vol. 29, No 3: pg. 427-460 (2005)

47. Karahanna, E., R. Agarwal, C. M. Angst, Reconceptualizing Compatibility Beliefs in Technology Acceptance Research, MIS Quarterly, Vol. 30, No 4: pg. 781-804 (2006)

48. Paul, D. L., R. R. McDaniel Jr, Field Study of the Effect of Interpersonal Trust on Virtual Collaborative Relationship Performance, MIS Quarterly, Vol. 28, No 4: pg. 183-227 (2004)

49. Jasperson, J., P. E. Carter, R. W. Zmud, A Comprehensive Conceptualization of PostAdoptive Behaviors Associated with Information Technology Enabled Work Systems, MIS Quarterly, Vol. 29, No 3: pg. 525-558 (2005)

50. Gattiker, T. F., D. L. Goodhue, What Happens after ERP Implementation: Understanding the Impact of Interdependence and Differentiation on Plant-Level Outcomes, MIS Quarterly, Vol. 29, No 3, pg. 559-585 (2005)

51. Kummer, T.-F.; Leimeister, J. M. \& Bick, M., On the Importance of National Culture for the Design of Information Systems. In: Business \& Information Systems Engineering, Ausgabe/Number: 6, Vol. 4, Erscheinungsjahr, Seiten/Pages: 317-330 2012 